\title{
THE LOCATION OF ESCHERICHIA COLI IN THE PIG INTESTINE
}

\author{
J. B. R. ARBUCKLE \\ Department of Animal Husbandry, Royal Veterinary College, \\ Potters Bar, Hertfordshire
}

\section{PlateS XXX-XXXII}

ADHERENCE of certain strains of human enteropathogenic Escherichia coli to intestinal epithelium has been demonstrated in ligated segments of the small intestine of rabbits (Drucker, Yeivin and Sacks, 1967). Smith and Halls (1968) enumerated a porcine enteropathogenic strain of $E$. coli in wall scrapings and in contents of the small intestine of pigs and found higher numbers of the organism in wall scrapings than in contents in the anterior small intestine, and considered this evidence of bacterial adhesion to the intestinal epithelium. The present study was undertaken to determine with more precision the site of porcine enteropathogenic strains of $E$. coli in the pig bowel. Ligated intestinal loops were not used since the prevention of normal caudal movement of ingesta by ligation may predispose to bacterial adhesion.

Knowledge of the location of enteropathogenic bacteria is not only of interest in the pathogenesis of such infections, but if the intestinal mucosa has an immunological role by virtue of local antibody synthesis (Crabbé, Carbonara and Heremans, 1965; Porter and Allen, 1969), then it is also important to know the site of antigen against which such antibody may be directed.

\section{MATERIALS AND METHODS}

Pigs

Two natural cases of post-weaning coliform diarrhoea in $6 \frac{1}{2}$ - and 9-wk-old pigs were obtained from one herd of Large White pigs.

Large White piglets were used for the experimental reproduction of neonatal $E$. coli diarrhoea. The piglets were removed from the sow within the first two days of life and transferred to an isolation pen.

\section{Bacteriology}

The piglets were given enteropathogenic strains of $E$. coli grown on $0 \cdot 1$ per cent. glucose agar for $18 \mathrm{hr}$ at $37^{\circ} \mathrm{C}$. The growth was washed off in $7 \mathrm{ml}$ of sterile saline and the inoculum placed at the back of a piglet's throat. Bacterial counts of the inocula, estimated by the Miles and Misra method (Miles, Misra and Irwin, 1938), were approximately $4 \times 10^{9}$. The enteropathogenic strains of $E$. coli given to piglets were Abbotstown \{O149:K91(B), K88a, c(L)\}, G205\{O8 : K87(B), K88a, c(L)\} and G1253 \{O147 : K89(B), K88a, c(L)\}. A non-enteropathogenic strain of $E$. coli, P30, was given to three piglets immediately after birth, before they had access to colostrum. Rectal swabs, taken from piglets after administration of bacteria, were inoculated on 7 per cent. bovine blood agar plates and MacConkey

Received 30 Sept. 1969; accepted 29 Oct. 1969.

J. MED. MICROBIOL.-VOL. 3 (1970) 
plates and incubated at $37^{\circ} \mathrm{C}$ overnight. If the inoculated strain of $E$. coli had established itself in profusion in the rectal flora, as occurs in natural outbreaks of disease, the piglet was killed with intravenous sodium pentobarbitone; if the inoculated $E$. coli was not present in profusion, then the inoculation was repeated until a profuse growth of the inoculated organism was recovered from a rectal swab.

In one series of experiments, eight piglets were each given a single dose of $E$. coli Abbotstown, containing approximately $5 \times 10^{9}$ bacteria, and they were killed at different intervals after dosage.

Two healthy piglets, which had not been given any strain of $E$. coli, were removed from the sow at 2 days of age and killed.

Portions of intestine, adjacent to those examined histologically, were cultured on blood agar and MacConkey plates. After overnight incubation at $37^{\circ} \mathrm{C}$, the identity of colonies of $E$. coli was determined by a slide agglutination test with $E$. coli $\mathrm{OK}$ antisera.

\section{Histology}

The intestinal tract was removed from the abdomen immediately after death and portions of the duodenum, jejunum and ileum, and of the spiral and terminal colon were frozen on specimen holders with $\mathrm{CO}_{2}$ gas. In a more detailed series of experiments, the small intestine was arranged into seven equal lengths after unravelling and the central portion of each length was frozen. The first small-intestinal segment was closest to the stomach and the last segment was closest to the caecum.

Sections $5 \mu \mathrm{m}$ thick were cut in a Slee cryostat at $-20^{\circ} \mathrm{C}$ and fixed by $3-5$ minutes' immersion in cold methanol at $4^{\circ} \mathrm{C}$.

Fluorescent antibody staining. The indirect method was used. Staining times were $\frac{1}{2} \mathrm{hr}$ at room temperature in a moist chamber; the sections were first stained with a 1 in 4 dilution of $E$. coli $\mathrm{OK}$ antiserum homologous to the inoculated organism and they were then stained with a 1 in 8 dilution of an anti-rabbit-globulin conjugated with fluorescein isothiocyanate (Nordic). The sections were washed for at least $10 \mathrm{~min}$. in three changes of phosphate-buffered saline $p \mathrm{H} \mathrm{7.2}$ after each staining procedure, and mounted in Polarfluor $\mathrm{B}$ (Polaron). Control slides were identical sections in which the intermediate layer was either a 1 in 4 dilution of absorbed homologous $E$. coli OK antiserum or a 1 in 4 dilution of normal rabbit serum, and unstained sections.

The fluorescence microscope was fitted with a $12 \mathrm{~V} 100 \mathrm{~W}$ quartz iodine lamp and a dark-ground condenser. The primary filter was a $1.5 \mathrm{~mm}$ thickness of BG12 and the secondary filter was a Wratten 12 gelatin filter. The sections were examined and interpreted before their identity was known.

Ilford HP4 black-and-white panchromatic film was used for fluorescence photomicrography, exposure times of $5 \mathrm{~s}$ being allowed. Kodak Panatomic-X black-and-white film was used for light photomicrography with exposure times of 0.04-1.0 s.

A conventional Gram-staining procedure was also performed on cryostat sections of intestinal tissue.

\section{RESULTS}

\section{Natural cases of post-weaning coliform diarrhoea}

Two weaned pigs were killed when affected with diarrhoea. Profuse cultures of $E$. coli Abbotstown were recovered from the intestines of both pigs except from the duodenum where Abbotstown was present in mixture with nonhaemolytic $E$. coli. Fluorescent staining revealed specific fluorescence on smallintestinal villous edges of both pigs. Figs. 1 and 2 show strong fluorescence around the jejunal villi of the 9-wk-old pig; fig. 3 is a control section, treated with absorbed $E$. coli $\mathrm{OK}$ Abbotstown antiserum, from the same pig. Slight manipulation of the fine adjustment control of the microscope revealed that the 
fluorescent edging on the villi consisted of bacteria. Fig. 1 shows that the major part of the fluorescence is located between the edges of adjacent villi; none-theless, a distinct space can be distinguished between the fluorescence on adjoining villous edges in many sites, and this probably indicates that the bacteria are on the villous edges rather than merely wedged in the space between adjacent villi. Few fluorescent bacteria are present in the lumen. Fig. 2 illustrates the location of $E$. coli Abbotstown on free villous borders as well as on adjacent villous edges; the fluorescent mass apparently in the lumen of this figure is related to a neighbouring piece of tissue of this section. A fluorescent edging was found on some villi in the jejunum and ileum, but not on the duodenal villi of either pig. Figs. 4 and 5 are Gram-stained sections from the same clinical case: fig. 4 demonstrates a densely staining region on the periphery of the villi, which is Gramnegative, and fig. 5 shows that under higher magnification this dense region consists of bacilli immediately outside the epithelial cells of the villi. The 9-wkold pig was killed when affected with a profuse watery diarrhoea and it was therefore considered representative of an established clinical case of post-weaning coliform diarrhoea, whereas the $6 \frac{1}{2}$-wk-old pig was killed when diarrhoea had been present for 3 days and clinically the pig appeared to be recovering from the disease. Fluorescence was present on considerably fewer villi in the $6 \frac{1}{2}$-wkold pig and the degree of fluorescence on these villi was also less than in the 9-wk-old pig.

The location of $E$. coli Abbotstown in the colon of these pigs differed from that in the small intestine. Numerous fluorescent bacteria were present in the colonic lumen, and in some parts their numbers were so great as to constitute a solidly fluorescent mass. Usually a distinct space could be discerned between this central mass and the colonic mucosa, but sometimes the fluorescent mass was contiguous with the colonic mucosa. Fig. 6 illustrates a piece of colonic mucosa and a jejunal villus from the 9-wk-old pig and the marked contrast between fluorescence on the colonic and that on the jejunal mucosa is evident.

\section{Experimental reproduction of neonatal diarrhoea in piglets}

Two piglets were dosed with $E$. coli Abbotstown, one piglet with $E$. coli G205 and one with $E$. coli G1253. Diarrhoea was reproduced in all four piglets and the inoculated bacteria were recovered in profusion from all intestinal sites. A specific fluorescent edging was found on villi in the jejunum and ileum of all four piglets and on the duodenal villi of the two piglets dosed with Abbotstown, but not on the duodenal villi of the piglets dosed with G205 and G1253. Fluorescent bacteria, in addition to being found on villous edges, were also frequently observed in the mouths of intestinal crypts in the small intestine, but they were rarely found in the basal region of these crypts. Fig. 7 illustrates the strong fluorescence of $E$. coli Abbotstown on basal villous edges and in the mouths of two intestinal crypts, but fluorescence is otherwise absent in the crypt region; the muscularis mucosae can be seen in the lower part of this figure. The fluorescent bacteria in the colon were located primarily in the lumen. Only very occasional isolated fluorescent bacteria were observed on the colonic 
mucosa; sometimes dense masses of fluorescent bacteria extended between the colonic lumen and the mucosa, but often a space was present between the bacteria and the mucosa.

\section{Control piglets}

A non-enteropathogenic strain of $E$. coli, P30, was given orally to three piglets. No diarrhoea occurred in the piglets, but profuse cultures of this bacterium were recovered from their intestines after killing. Fluorescent bacteria were observed in the small-intestinal lumen and sometimes on the villous edges of all three piglets. However, the numbers of bacteria observed in these sites were small and their distribution differed from that of enteropathogenic strains of $E$. coli in that the non-enteropathogen usually occurred in the lumen and only small numbers were present on villous edges. None-the-less, numerous fluorescent bacteria were observed in the seventh small-intestinal segment of one piglet, and fig. 8 illustrates the location of $E$. coli $\mathrm{P} 30$ in this segment; most of the bacteria are present in the spaces between villi, but a few are present on villous edges. The situation of this non-enteropathogenic strain in the colon resembled that of enteropathogenic $E$. coli in the colon; large numbers of the non-enteropathogen occurred in the lumen and sometimes this fluorescent mass of bacteria was contiguous with the mucosa. Only occasional isolated fluorescent bacteria or small clumps of them were observed on the mucosa.

No enteropathogenic $E$. coli were identified in the enteric flora of two healthy piglets killed at 2 days of age. In Gram-stained sections, Gram-positive bacilli were observed on a few small-intestinal villi in both piglets, and similar organisms were also seen in the lumen. These organisms frequently had a beaded appearance and were probably lactobacilli: their sparse distribution on the villi of healthy piglets contrasted markedly with the dense aggregation of $E$. coli on numerous villi of pigs affected with $E$. coli diarrhoea.

\section{The development of attachment of enteropathogenic E. coli to villi}

The foregoing observations on natural and experimental cases of $E$. coli diarrhoea in pigs demonstrate bacterial attachment to small-intestinal villi; in order to study the development of this adhesion eight piglets were killed at various times after a single dose of $E$. coli Abbotstown. Seven similar sites of small intestine were examined in each pig.

The table summarises the results. Well-developed adhesion of $E$. coli Abbotstown to small-intestinal villi was present in the piglets killed $11 \frac{1}{2}, 20 \frac{1}{2}$ and $24 \frac{1}{2} \mathrm{hr}$ after inoculation. Bacterial adhesion was most prominent in the caudal small-intestinal segments, e.g., segments 5,6 and 7, and was less marked in the cranial segments, e.g., segment 2. No adhesion was observed in the first segment of two of these piglets, but two small areas of bacterial adhesion to the villi in this segment were observed in the piglet killed $20 \frac{1}{2} \mathrm{hr}$ after dosage. Some fluorescent bacteria were also present in the small-intestinal lumen, but the numbers there were much smaller than the numbers on and between the villi. Diarrhoea was reproduced in all three piglets, and profuse cultures of $E$. coli 


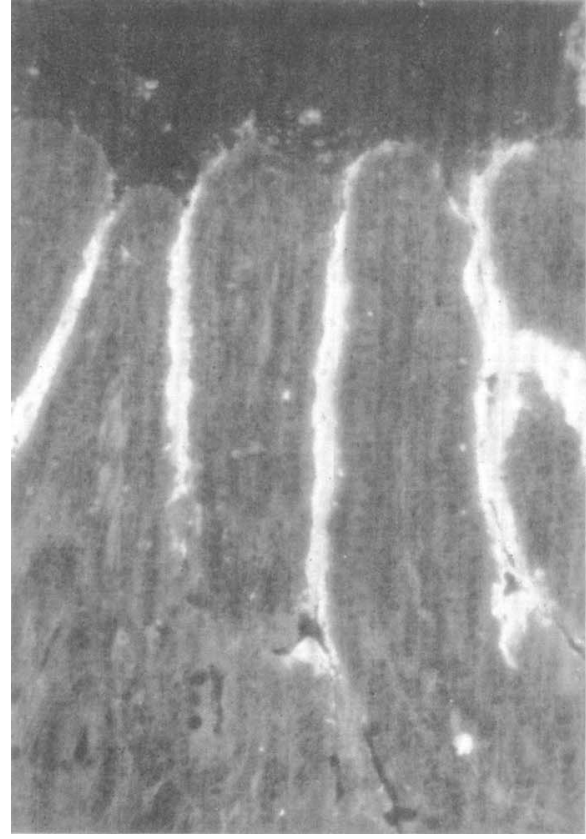

FIG. 1.-Fluorescence of E. coli Abbotstown on villous edge. Fluorescent antibody test (FAT) with $E$. coli Abbotstown antiserum. $\times 125$.

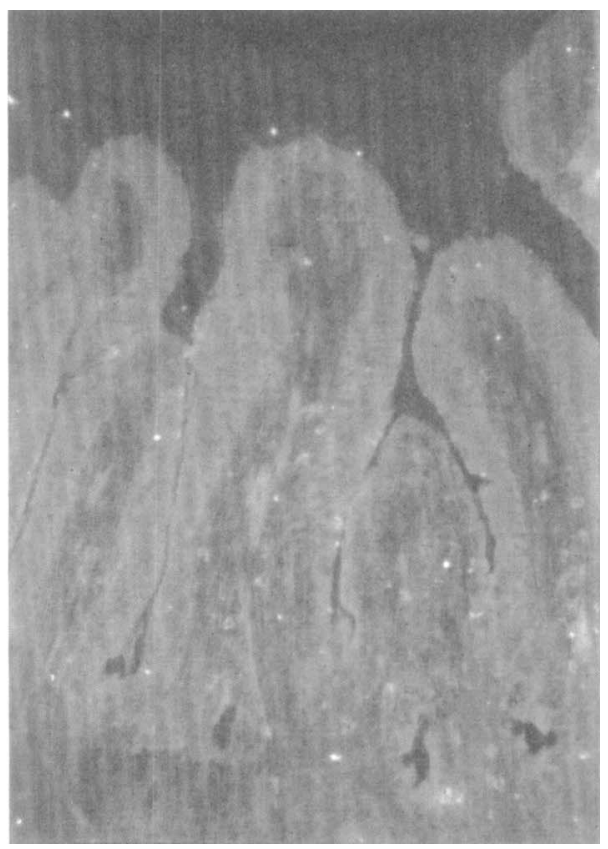

FiG. 3.-Control test: no fluorescence. FAT with E. coli Abbotstown antiserum absorbed with homologous organisms. $\times 125$.

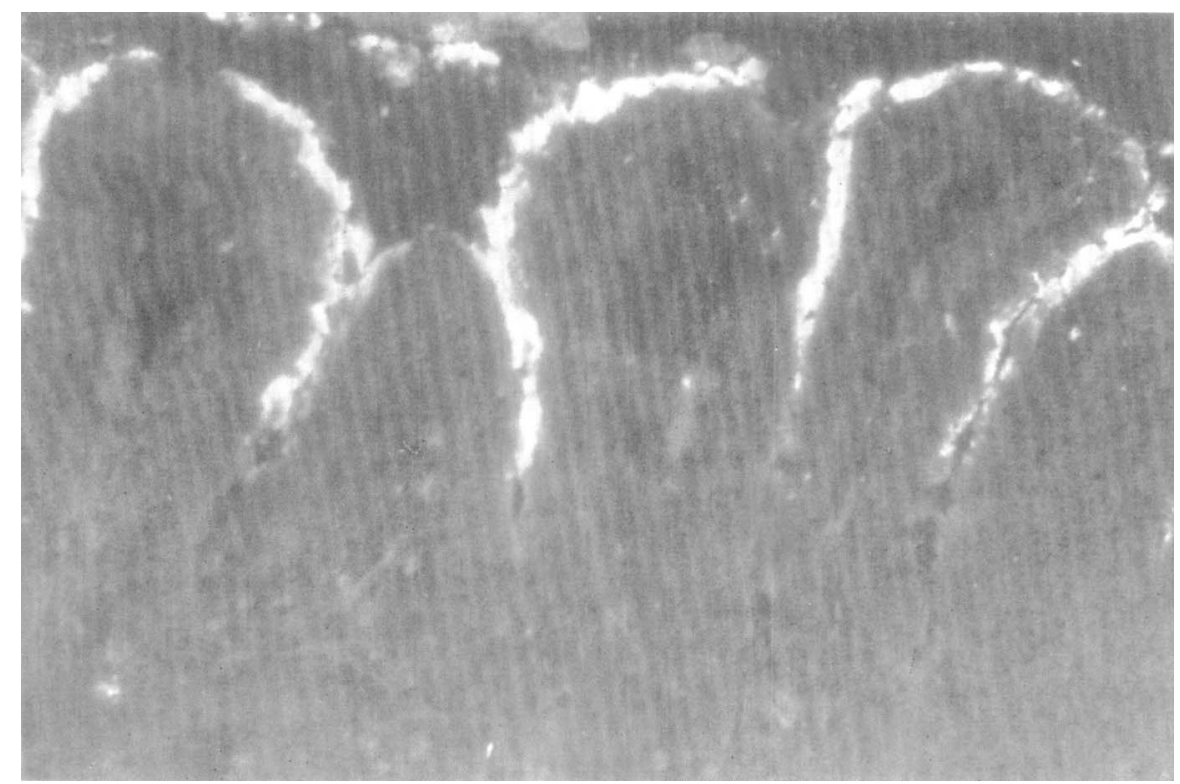

FIG. 2.-Fluorescence of $E$. coli Abbotstown on villous tips and edges. FAT with E. coli Abbotstown antiserum. $\times 165$.

FIGS. 1-3. Jejunum of weaned pig naturally affected with Escherichia coli Abbotstown diarrhoea. 
LOCATION OF E. COLI IN PIG INTESTINE

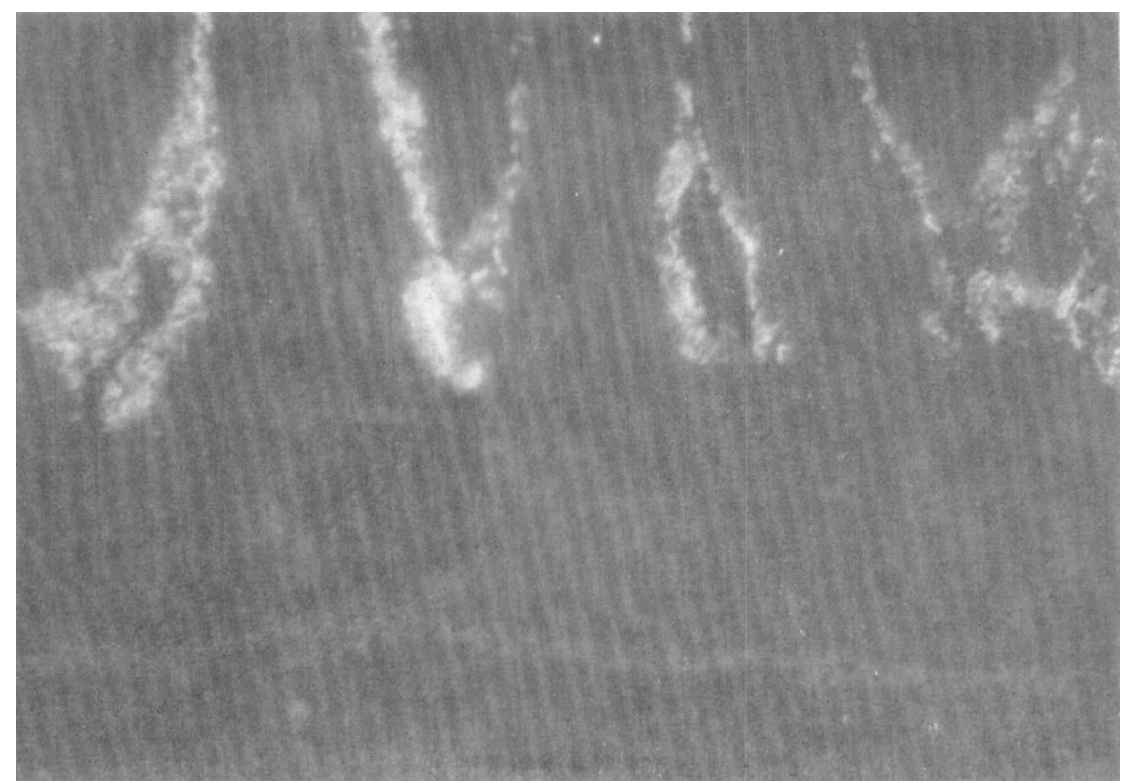

FiG. 7.--Pig given E. coli Abbotstown by mouth. Small intestine. E. coli Abbotstown fluorescence on basal villous edges and in the mouths of two crypts. FAT with homologous serum. $\times 165$.

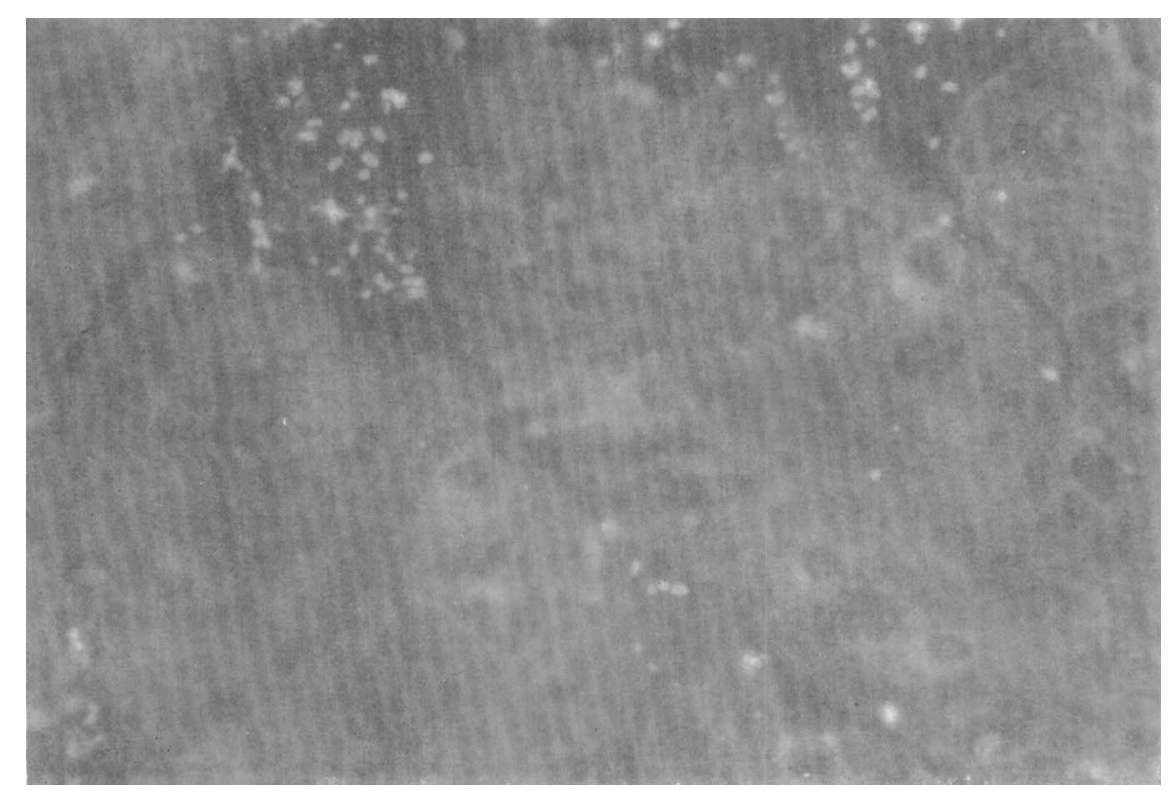

FIG. 8.-Pig given $E$. coli $\mathrm{P} 30$ by mouth. Small intestine. E. coli $\mathrm{P} 30$ fluorescence in intervillous spaces, with some bacteria on villous edges. FAT with homologous antiserum. $\times 660$. 


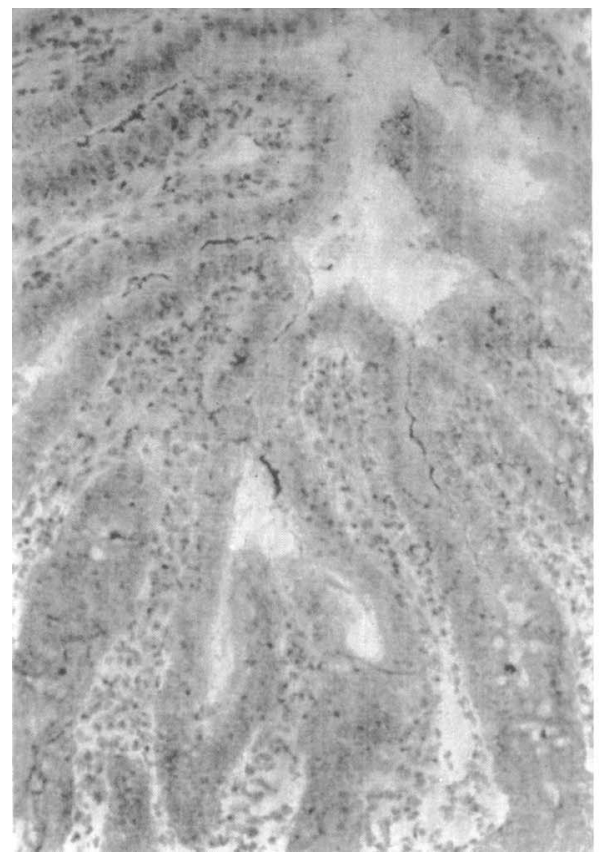

FIG. 4.- Jejunum. Densely staining regions round a number of villi. Gram. $\times 125$.

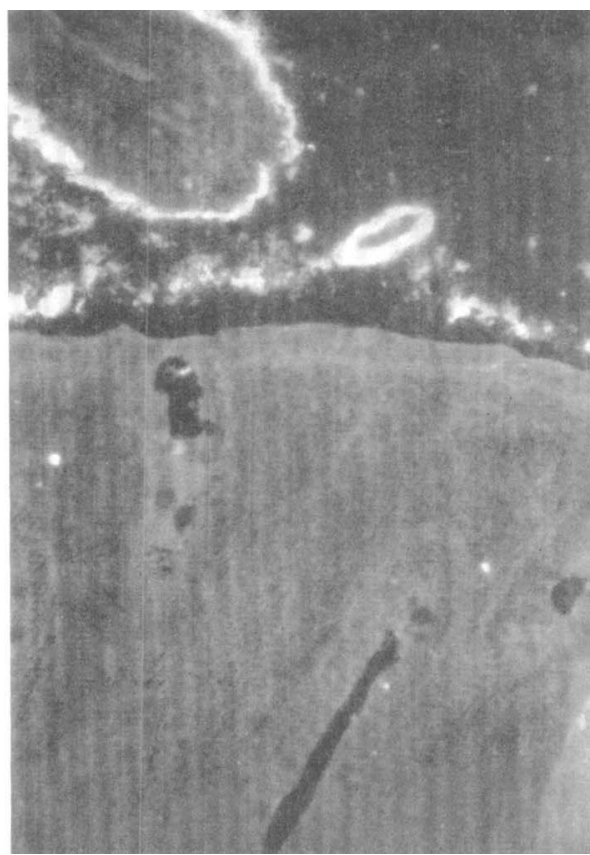

FIG. 6.--Colon and jejunal villus. Fluorescence on jejunal, but not on colonic mucosa. FAT with E. coli Abbotstown antiserum. $\times 125$.

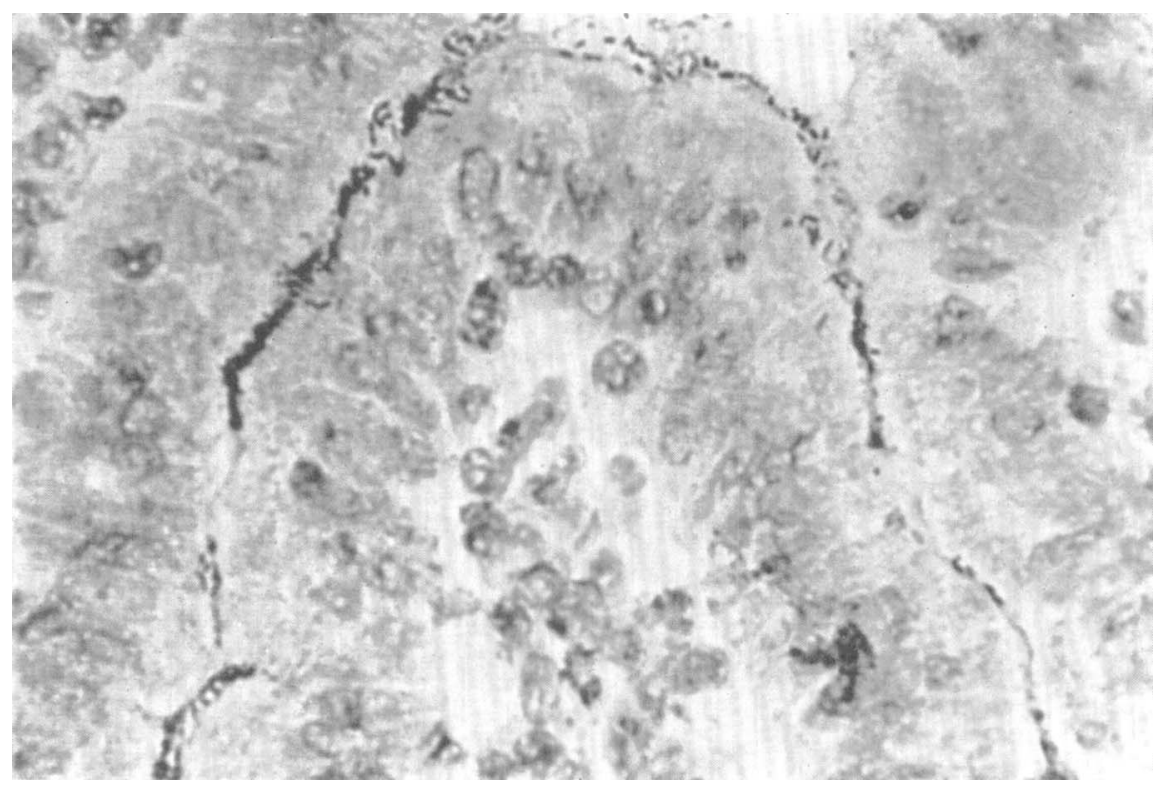

FIG. 5.- Jejunal villus. Densely packed bacilli immediately exterior to epithelial layer. Gram, $\times 660$.

FIGS. 4-6. Jejunum and colon of same pig as in figs. 1-3. 
This series of experiments therefore demonstrated that coliform attachment to villi commenced at about $6-7 \mathrm{hr}$ after dosage with an enteropathogenic strain of $E$. coli, and that the attachment was best developed when diarrhoea was well established clinically.

\section{Discussion}

Pathogenic intestinal bacteria have been classified by Takeuchi (1967) into three groups according to their site in the intestines: (1) pathogens that invade the intestinal mucosal barrier; (2) pathogens that attach themselves to intestinal epithelium but are not invasive; and (3) pathogens that neither penetrate nor attach themselves to intestinal epithelium, but none-the-less elicit symptoms.

The present paper presents evidence to indicate that, in natural and experimental cases of Escherichia coli diarrhoea in pigs, enteropathogenic strains of $E$. coli attach themselves to small-intestinal villi and thus can be classified in Takeuchi's intermediate group; previous observations on E. coli diarrhoea of pigs appear to have failed to demonstrate such adhesion. The bacteria were observed on the free border of villous epithelium and between adjoining villi; however, they were not considered invasive, since none was observed within epithelial cells except for very occasional organisms. In addition to being located on villi, enteropathogenic strains of $E$. coli were also observed within the apical region of intestinal crypts, but they were rarely observed within the basal region of crypts. This may be a consequence of the greater exposure of villi than of crypts to bacteria. The precise relation of enteropathogenic $E$. coli to intestinal epithelium can be determined only by electron microscopy, and Staley, Jones and Corley (1969) found that in starved newborn piglets $E$. coli is associated with the exfoliation of microvilli prior to the attachment of bacteria to the apical plasma membrane. The location of enteropathogenic $E$. coli on villous edges can be considered a lesion of coliform enteric disease in pigs since, although a non-enteropathogenic strain of $E$. coli was also found on villous edges, the numbers of the enteropathogenic bacteria on villi were very considerably greater than the numbers of the non-enteropathogenic strain in a similar situation. Furthermore, in healthy piglets only occasional bacteria, which were Grampositive bacilli, were found on a few villi. It may be that the enteropathogenic strains of $E$. coli are more adhesive than non-enteropathogenic strains, or perhaps the former strains can proliferate better once they have located themselves on villi. Drucker et al. (1967) also observed that human enteropathogenic and non-enteropathogenic strains of $E$. coli can adhere to villi in ligated small-intestinal segments of rabbits, but that the degree of adherence is greater with the enteropathogenic strains. Duguid et al. (1955) correlated the haemagglutination of erythrocytes by $E$. coli with the presence of fimbriae on the bacteria, and regarded the fimbriae as organs of attachment. Such fimbriae may also be effective in vivo in the adhesion of $E$. coli to intestinal epithelium.

Coliform attachment to villi was first detected 6-7 hr after dosage with an enteropathogenic strain of $E$. coli; before these times it was not observed, but after them it was well developed. Adhesion appears to commence in the terminal small intestine, since in one piglet killed $7 \mathrm{hr}$ after inoculation adhesion was 
Abbotstown were recovered in all cases from all small-intestinal segments but the first. The piglets were very weak and dehydrated when killed and were therefore considered representative of established clinical cases of neonatal coliform diarrhoea.

Some bacterial attachment to the basal parts of the villi in the seventh smallintestinal segment only was observed in one of the two piglets killed $7 \mathrm{hr}$ after

\section{TABLE}

The development of adhesion of enteropathogenic Escherichia coli to porcine small-intestinal villi

\begin{tabular}{|c|c|c|c|}
\hline $\begin{array}{l}\text { Time of killing after } \\
\text { inoculation of } E \text {. coli } \\
\text { Abbotstown (hr) }\end{array}$ & $\begin{array}{l}\text { Clinical state at time of } \\
\text { killing and time of first } \\
\text { detection of diarrhoea } \\
\text { (hr after inoculation) }\end{array}$ & $\begin{array}{l}\text { Bacterial adhesion } \\
\text { to villi }\end{array}$ & $\begin{array}{l}\text { Isolation of } E . \text { coli } \\
\text { Abbotstown from } \\
\text { small intestine }\end{array}$ \\
\hline $2 \frac{1}{2}$ & No diarrhoea & - in all segments & Profuse \\
\hline 5 & Diarrhoea: 5 & -in all segments & $\begin{array}{l}\text { In mixture with non- } \\
\text { haemolytic } E \text {. coli }\end{array}$ \\
\hline 6 & Diarrhoea: 4 & + in all segments & Profuse \\
\hline 7 & Diarrhoea: 6 & $\begin{array}{l}+ \text { in segment } 7 \\
\text {-in segments } 1 \rightarrow 6\end{array}$ & $\begin{array}{l}\text { In mixture with non- } \\
\text { haemolytic } E \text {. coli }\end{array}$ \\
\hline 7 & Diarrhoea: 5 & -in all segments & $\begin{array}{l}\text { Profuse in some seg- } \\
\text { ments }\end{array}$ \\
\hline $11 \frac{1}{2}$ & $\begin{array}{l}\text { Diarrhoea: } 6 \frac{1}{2} \\
\text { Moribund }\end{array}$ & $\begin{array}{l}+ \text { in segments } 2 \rightarrow 7 \\
- \text { in segment } 1\end{array}$ & Profuse \\
\hline $20 \frac{1}{2}$ & $\begin{array}{l}\text { Diarrhoea: } 6 \frac{1}{2} \\
\text { Moribund }\end{array}$ & + in all segments & Profuse \\
\hline $24 \frac{1}{2}$ & $\begin{array}{l}\text { Diarrhoea: } \\
\text { not before } 9 \\
\text { Moribund }\end{array}$ & $\begin{array}{l}+ \text { in segments } 2 \rightarrow 7 \\
- \text { in segment } 1\end{array}$ & Profuse \\
\hline
\end{tabular}

inoculation. This adhesion was less well developed than in those piglets killed at later times and appeared to be an early stage in the development of adhesion. $E$. coli Abbotstown was not recovered in large numbers from any of the intestinal cultures of this piglet, and diarrhoea was first detected $6 \mathrm{hr}$ after inoculation. This piglet was therefore probably in the early clinical stages of neonatal coliform diarrhoea. No fluorescence was observed on the villi of the other piglet killed $7 \mathrm{hr}$ after inoculation.

Fluorescent bacteria were observed on villi in all the small-intestinal segments of the piglet killed $6 \mathrm{hr}$ after inoculation. The fluorescence was restricted either solely or mainly to the basal parts of the villi in the first three intestinal segments whereas in the four terminal segments the fluorescence was present on both the apical and basal regions of the villi.

No fluorescence was observed on the villi of either of the piglets killed $2 \frac{1}{2}$ and $5 \mathrm{hr}$ after inoculation. 
detected in the seventh small-intestinal segment only. Further, in other piglets, the amount of fluorescence located on villi in the caudal small-intestinal segments was greater than that on villi in the cranial ones, which also probably implies that adhesion commences in the caudal segments. It would also seem that adhesion commences in the basal region of villi and then progresses up the villi because in some piglets showing the earlier stages of adhesion the bacteria were observed only on the villous bases and not on their apices. It is possible that the region around villous bases provides an environment more sheltered against peristaltic flow and this may render the site more suitable for the development of bacterial adhesion than the environment at villous tips. Similarly, reduced motility in the ileum would tend to favour the initiation of coliform adhesion in this part of the small intestine. Neimeier (1941, cited by Martin, 1965) observed that the ileocaecal valve of pigs closes at times and stops the movement of food in the ileum. Smith and Orcutt (1925) observed that the small-intestinal mucosa of calves killed in an advanced stage of $E$. coli diarrhoea was carpeted with layers of $E$. coli attached to the top plates of epithelial cells, and that this carpeting sometimes extended from the ileocaecal valve almost to the duodenum before death.

No difference was observed in the location of enteropathogenic or nonenteropathogenic $E$. coli in the colon. The bacteria were located primarily in the lumen, but sometimes a mass of them extended from the lumen to the mucosa. Occasional isolated bacteria or small groups of them were observed on the colonic mucosa, but their numbers were markedly less than those occurring on the mucosa of the small intestine. Perhaps the villous structure of the small-intestinal mucosa presents a more suitable surface for the development of coliform adhesion than the smoother surface of the colonic mucosa. The location of $E$. coli on the colonic mucosa had the appearance of being a consequence of the intraluminal situation of this bacterium, whereas in the small intestine enteropathogenic strains of $E$. coli appeared to be located primarily on the villous epithelium.

\section{SUMMARY}

The situation of enteropathogenic strains of Escherichia coli in the porcine intestine of naturally occurring and experimentally reproduced cases of $E$. coli diarrhoea was studied mainly by fluorescent staining techniques. Three different enteropathogenic strains were found on villi of the small intestine, but only small numbers of these bacteria were found on the colonic mucosa except when they were contiguous with the mass of bacteria in the lumen. A non-enteropathogenic strain of $E$. coli was found on villi of the small intestine in small numbers. Occasional Gram-positive bacilli were observed on a few villi in the intestines of two healthy piglets.

Coliform attachment to villi was found to be most marked when diarrhoea was clinically well established, but such attachment was also sometimes observed during the early clinical stages of diarrhoea. It is therefore considered that adhesion of $E$. coli to small-intestinal villi is a significant lesion of porcine diarrhoea associated with enteropathogenic strains of E. coli. 
I wish to thank the Meat and Livestock Commission for financial assistance during this work, Mr J. E. T. Jones for his interest, Dr H. W. Smith for the non-enteropathogenic strain of $E$. coli and Miss P. Myland for capable technical assistance.

\section{REFERENCES}

Crabbé, P. A., Carbonara, A. O., AND 1965. Lab. Invest., 14, 235. Heremans, J. F.

Drucker, M. M., Yeivin, Rina, AND 1967. Israel J. Med. Sci., 3, 445.

SACKS, T. G.

Duguid, J. P., Sмith, Isabel W., 1955. J. Path. Bact., 70, 335. Dempster, G., AND Edmunds, P. N.

MARTin, J. E. . . . . . . . . . . 1965. In Diseases of swine, 2nd ed., edited by

H. W. Dunne, Iowa, p. 64.

Miles, A. A., Misra, S. S., ANd Irwin, 1938. J. Hyg., Camb., 38, 732. J. O.

Porter, P., And Allen, W. D. . . . 1969. Proc. I Int. Pig Vet. Soc., Cambridge,

Smith, H. W., AND Halls, SheIla . . 1968. J. Med. Microbiol., 1, 45.

SMith, T., AND ORCUTt, MARION L. . . 1925. J. Exp. Med., 41, 89.

Staley, T. E., Jones, E. W., And Corley, 1969. Amer. J. Path., 56, 371.

L. D.

TAKEUCH, A. . . . . . . . . 1967. Ibid., 50, 109. 